
\title{
25 Research Soure \\ Effectiveness of chiropractic modality on chronic low back pain patients, A quasi-experimental study
}

\section{Behdokht Aleali}

Shiraz University of Medical Sciences

Mohammad Hossein Sharifi

Shiraz University of Medical Sciences

Malihe Sousani

Shiraz University of Medical Sciences

Alireza Salehi ( $\nabla$ salehialireza45@yahoo.com )

Research center for Traditional Medicine and History of Medicine

Research

Keywords: Chiropractic, Low back pain, Complementary medicine

Posted Date: September 28th, 2020

DOI: https://doi.org/10.21203/rs.3.rs-81428/v1

License: (c) (1) This work is licensed under a Creative Commons Attribution 4.0 International License. Read Full License 


\section{Abstract}

\section{Background}

Low back pain (LBP) is one of the most prevalent diseases in the developed and developing countries, which imposes high socioeconomic burden on both the individual and the community. There are limited studies that explain the clinically meaningful impact of chiropractic modality in chronic LBP.

Method

This is a quasi-experimental study. Participants were patients who had referred to Shiraz private chiropractic clinics with more than three month chronic LBP and had no pathologic abnormalities. Data were collected in two stages, baseline visit and 8 weeks after treatment. The effect of intervention measured throughout three questionnaire including Roland Morris Disability Questionnaire (RMDQ), Numerical Rating Scale (NRS) and self-assessment Global Rating of Change (GRC) questionnaires.

Result

141 patients analyzed, the mean age of participants was $40.18 \pm 10.42$ years of old and $40(28.4 \%)$ were male. The mean duration of LBP was $56.73 \pm 45.11$ months. Before and after intervention, based on RMDQ and NRS data, indicated that the mean difference \pm Standard Deviation was $5.54 \pm 4.95$ and 2.44 \pm 1.64 the statistically significant difference $(P<0.001)$ and $(P<0.001)$ among all demographic and clinical characteristic variables, except job status. The mean \pm SD of GRC was $56.13 \pm 33.03 \%$. Based on the RMDQ cut-off point, 88 participants $(62 \% ; 95 \% \mathrm{Cl}: 50-70)$ have been affected by chiropractic with a clinically meaningful effect. In addition, the chiropractic may be an effective therapeutic modality in treating patients with mild, moderate, or even severe MRI findings.

Conclusion

Complementary chiropractic treatment amongst chronic LBP patients may be an appropriate adjuvant to conventional treatments to improve disability and pain intensity reduction in both genders.

\section{Introduction}

Low Back Pain (LBP) is one of the most prevalent diseases in the developed and developing countries, which imposes high socioeconomic burden on both the individual and the community. The direct cost of LBP in the United States in 2010 was $\$ 34$ billion dollars and estimated to be $\$ 200$ billion, if we add indirect costs including lost workplace productivity $(1,2)$. After common cold, LBP is the second leading cause of referral to physicians, with 18 million people seeking care annually (2). In Iran, the prevalence of LBP is $51 \%$, which means half of Iranians have experienced it at least once in their lifetime (3).

Recently, the inclination to use complementary medicine, including chiropractic therapy, in addition to the conventional treatments has increased (4). On the other hand, current therapeutic methods for LBP, 
including non-steroidal anti-inflammatory drugs, opioids in mild and spinal fusion, epidural injections of steroids for moderate to severe pain, have been shown to have limited effects in the treatment of chronic LBP (5). Furthermore, many of these therapies have undesirable side effects. This calls for reevaluation of low-risk and cost-effective non-pharmacological treatments (6). Several studies have shown that patient's satisfaction with chiropractic care is more than the current medical care (7). Chiropractic is now widely used as a complementary treatment to treat back pain. In the modern sense, chiropractic was established in 1895 by Daniel David Palmer in America (8). Chiropractic intervention is mainly performed on spine region; nevertheless, it has been documented to be effective in other regions including extremities, neck muscles and skull (9-11). In Denmark, at least one-third of patients with LBP initiate their treatment with chiropractic (12). Annually, at least seven and a half percent of the United States population seek chiropractic services, representing more than 190 million patient visits each year (13).

Various outcomes have been reached in the evaluation of chiropractic intervention. Several studies documented high rates of patient satisfaction with chiropractic care in comparison to other therapeutic modalities (14-16). In addition, Ernest et al. systematic review compared the effect of chiropractic in the treatment of LBP with medication, physical methods, exercise programs, sham and no treatment groups and showed that chiropractic was more effective than physiotherapy, sham, and no treatment groups, but less effective than medical care (17).

Today, the National Chiropractic Association is active in more than 70 countries including Iran (18). Given the high prevalence of LBP in the community and the increasing number of patients, it is a necessity to conduct studies to evaluate the effectiveness of chiropractic approaches. To the best of our knowledge, in Iran no study has investigated; thus, we evaluated the effectiveness of chiropractic amongst chronic LBP patients and its correlation with other epidemiological characteristics.

\section{Methods}

\section{Study design, participants and sample size}

This is a quasi-experimental study. Participants were patients who had referred to Shiraz private chiropractic clinics with chronic LBP who had the first chiropractic visit and had no pathologic abnormalities. Inclusion criteria consisted of being at least eighteen-years-old, mechanical LBP greater than 3 months, and living in Fars province. Exclusion criteria consisted of non-somatic LBP, presence of any comorbidity that could affect the treatment prognosis, pregnancy, chiropractic treatment less than 3 months ago, contraindication of manipulation including coagulation disorders or usage of anticoagulant agents or corticosteroids, inaccessibility to an available phone and drug addiction. Sample size was based on the study by Eklund et al. using the sample size determination formula in quasi-experimental studies, and by considering the type I error of $5 \%(\alpha=0.05)$, and type II error of $20 \%(\beta=0.20)$ the sample size was determined at 141 patients (19).

\section{Data Collection and Questionnaire}


Data were collected in two stages, baseline visit and 8 weeks after treatment. The first stage was at the baseline visit and before the intervention. Data were collected through questionnaires. The first questionnaire included demographic information such as age, gender, weight, height, literacy level, place of residence, marital status, occupation, economic status, duration of LBP, and history of LBP in the family. Economic status was categorized into four groups regarding household income distribution in Shiraz, Iran as follows; 1- lower than intermediate: between 250 and 634 United States Dollars (USD), 2intermediate: between 634 and 1184 USD, and 3- higher than intermediate: above 1184 USD in 2017 (20).

Moreover, Magnetic Resonance Imaging (MRI) was performed using a 3.0-T unit (Symphony Quantum, Siemens AG Medical Solutions). The patients' lumbosacral spine MRI was evaluated and according to the extent of the intervertebral disc injury, patients were divided into three groups: all subjects were grouped into three categories: mildly degeneration (Grade II), moderately degeneration (Grade III), and severely degeneration (Grade IV and Grade V) (21). The following three questionnaires were used to evaluate the effectiveness of the intervention.

\section{Roland Morris Questionnaire}

Assessment of disability due to LBP was performed, using the standard Roland Morris Disability Questionnaire (RMDQ) before and after the intervention. The RMDQ is a patient-administered selfreporting instrument. It is a 24 item questioner with possible scores ranging from 0 level (the less disability) to 24 level (severe disability). Each item includes a sentence in which the qualification of LBP is interpreted. Patients only ticked sentences indicating their LBP during the past 24 hours. This questionnaire has Cronbach's alpha $=0.84$ to 0.96 and $r=0.83$ to 0.9 (22). The validity and reliability of this questionnaire was obtained by Mousavi et al. in 2006 in Iran (23). The RMDQ was chosen due to its higher sensitivity in detecting changes in disability amongst patients with LBP, which was utilized in clinical trial studies more than other similar questionnaires $(24,25)$. RMDQ was answered by the patients at baseline visit and eight weeks after the onset of treatment. Based on the previous study a $30 \%$ (7 level) decrease in the RMDQ scale was defined as clinically meaningful effect (26).

\section{Numerical Rating Scale (NRS)}

NRS is a patient-administered self-reporting instrument. The participants were asked to rate their average level of LBP within the past week on an ordinal 11-point scale ( $0=$ no LBP, $10=$ worst possible LBP) before and 8 weeks after the onset of treatment. Each three scores indicated a level of pain as follows: 0 = no pain, 1 to $3=$ mild pain, 4-6 = moderate pain, and 7-10 = severe pain. The NRS has excellent metric properties and is commonly used in Randomized Clinical Trials (RCTs), and has validated as a reliable measure (27). The sensitivity of the NRS for LBP was evaluated by Childs et al., who confirmed its sensitivity in 2005 (28). This questionnaire was used by Forutani et al., 2018 in Iran and was shown to be valid and reliable (29).

\section{Global Rating of Change (GRC)}


The GRC questionnaire was used during the follow-up stage. This is a patient-administered self-reporting instrument, which evaluates the change in LBP after the intervention through a single-question questionnaire that evaluates the global LBP improvement. Participants were asked to rate their perceived LBP improvement 8 weeks after the onset of treatment. The validity and reliability of this questionnaire was confirmed by Foroutani et al., 2018 in Iran (29).

\section{Intervention}

The treatment stages include manual techniques that emphasize on the processes of adjustment, manipulation and to some extent, mobilization and soft tissue reflex techniques. It also includes rehabilitation programs, psychosocial aspects of patient's care, patient's education on spine health, and proper posture. Our intervention included six sessions, every other day during two weeks. Each treatment session lasted for about twenty minutes, and interventions were selected according to each patient's condition, as follows:

1. Activator: A device used to correct spine rotation by asking the patient to perform a specific maneuver for each vertebra, then checking the patient's legs to find any vertebral rotation. If there was any vertebral rotation, the activator would hit the transverse process to adjust all the vertebras.

2. Drop table: A table with mobile cervical, lumbar and pelvic parts and is most commonly used to adjust hip rotation.

3. Arthrostem: It resembles an activator, but has stronger pulses and is used to align the spine and stimulate the muscles.

4. Flexion-destruction bed, creates flexion and extension to reduce muscle spasm and cause rehydration of the intervertebral discs.

5. Finally, Manipulation to adjust the spine.

Then patients were advised to avoid activities that could cause LBP relapse. Patients were explained that the best outcome would be achieved six to eight weeks after treatment, when the joints inflammation were relieved. The second stage was followed up via telephone call.

\section{Statistical analysis}

The collected data was analyzed by SPSS 24 software (Version 22, IBM Corp, Armonk, NY). Frequencies and percentages were calculated for all variable categories. In this study, in addition to measuring the descriptive statistics such as mean, Standard Deviation (SD), t-test for quantitative variables analysis and Chi-square test for qualitative variables analysis and the effect of gender on the intensity of MRI findings. Linear regression statistical models and logistic analysis were used to examine the factors affecting the effectiveness of the intervention in RMDQ instrument separately. Independent t-test, ANOVA, Paired-T test and Chi-square test were used to compare groups. Differences were considered significant at a two-tailed $P<0.050$ for all statistical analyzes. 


\section{Results}

\section{Population characteristics}

A total of 187 patients with chronic LBP were recruited during 2019-20. Of which 37 patients had neck pain in addition to LBP and were excluded from the study. Finally, 141 patients analyzed (Fig. 1). The mean age of participants was $40.18 \pm 10.42$ years of old and $40(28.4 \%)$ were male. Analysis showed that there was no significant difference in the degree of MRI (mild, moderate and severe) between male and female $(P=0.930)$. The mean duration of LBP was assessed in different groups and it was shown that disease duration in females (63.6 months \pm 45.91 ) was more than males (39.35 months \pm 38.33 ).

\section{Results of intervention effect on pain disability based on RMDQ questionnaire}

Before intervention mean \pm SD of pain disability scores was $13.5 \pm 4.89$ scores that changed to $7.51 \pm 5.6$ after intervention $(P<0.001)$ (Fig. 2). Analysis showed that mean $\pm S D$ scores of RMDQ among all demographic and clinical characteristic variables were significant before and after intervention. In addition, just the job variable had significant difference between subgroups $(P=0.004)$. In this respect, unemployment, as subgroups variable, received highest treatment score (mean difference $9.32 \pm 5.94$ ), compared employment (mean difference $6.98 \pm 5.10$ ) (Table 1). 
Table 1

Mean \pm SD pain-disability (RMDQ) scores based on demographic variables

\begin{tabular}{|c|c|c|c|c|c|c|}
\hline Variables & subgroups & $\begin{array}{l}\text { Frequency } N \\
\text { (\%) }\end{array}$ & $\begin{array}{l}\text { Before } \\
\text { mean } \pm \\
\text { SD }\end{array}$ & $\begin{array}{l}\text { After } \\
\text { mean } \pm \\
\text { SD }\end{array}$ & $\begin{array}{l}P^{*}- \\
\text { value }\end{array}$ & $\begin{array}{l}P^{* k} \text { - } \\
\text { value }\end{array}$ \\
\hline \multirow[t]{2}{*}{ Age } & $\leq 40$ & $40(28.4)$ & $\begin{array}{l}12.25 \pm \\
4.69\end{array}$ & $\begin{array}{l}6.49 \pm \\
5.16\end{array}$ & $<.001$ & \multirow[t]{2}{*}{0.467} \\
\hline & $>40$ & 101 (71.6) & $\begin{array}{l}14.29 \pm \\
4.96\end{array}$ & $\begin{array}{l}9.1 \pm \\
5.92\end{array}$ & $<.001$ & \\
\hline \multirow[t]{2}{*}{ Gender } & Male & $40(28.4)$ & $\begin{array}{l}10.95 \pm \\
4.89\end{array}$ & $\begin{array}{l}6.65 \pm \\
5.75\end{array}$ & $<.001$ & \multirow[t]{2}{*}{0.061} \\
\hline & Female & $101(71.6)$ & $\begin{array}{l}13.88 \pm \\
4.65\end{array}$ & $\begin{array}{l}7.85 \pm \\
5.53\end{array}$ & $<0.001$ & \\
\hline \multirow[t]{2}{*}{ Marital status } & Single & $21(14.9)$ & $\begin{array}{l}10.95 \pm \\
4.44\end{array}$ & $\begin{array}{l}5.57 \pm \\
4.53\end{array}$ & $<.001$ & \multirow[t]{2}{*}{0.875} \\
\hline & Married & $120(85.1)$ & $\begin{array}{l}13.42 \pm \\
4.88\end{array}$ & $\begin{array}{l}7.85 \pm \\
5.71\end{array}$ & $\begin{array}{l}< \\
0.001\end{array}$ & \\
\hline \multirow[t]{2}{*}{ Education } & Diploma or less & $67(47.5)$ & $\begin{array}{l}14.89 \pm \\
4.46\end{array}$ & $\begin{array}{l}9.04 \pm \\
5.85\end{array}$ & $<.001$ & \multirow[t]{2}{*}{0.479} \\
\hline & Academic & $74(52.5)$ & $\begin{array}{l}11.38 \pm \\
4.66\end{array}$ & $\begin{array}{l}6.12 \pm \\
5.00\end{array}$ & $<.001$ & \\
\hline \multirow[t]{3}{*}{ Job } & Employed & $68(48.2)$ & $\begin{array}{l}11.82 \pm \\
4.50\end{array}$ & $\begin{array}{l}6.98 \pm \\
5.10\end{array}$ & $\begin{array}{l}< \\
0.001\end{array}$ & \multirow[t]{3}{*}{0.004} \\
\hline & Unemployed & $26(18.4)$ & $\begin{array}{l}14.04 \pm \\
4.60\end{array}$ & $\begin{array}{l}5.61 \pm \\
5.35\end{array}$ & $<.001$ & \\
\hline & Housewife & $47(33.3)$ & $\begin{array}{l}14.28 \pm \\
4.50\end{array}$ & $\begin{array}{l}9.32 \pm \\
5.94\end{array}$ & $<0.001$ & \\
\hline \multirow[t]{2}{*}{ Residence } & Small city & $57(40.4)$ & $\begin{array}{l}12.88 \pm \\
5.38\end{array}$ & $\begin{array}{l}7.37 \pm \\
5.80\end{array}$ & $<.001$ & \multirow[t]{2}{*}{0.937} \\
\hline & Large city & $84(59.6)$ & $\begin{array}{l}13.05 \pm \\
4.08\end{array}$ & $\begin{array}{l}7.72 \pm \\
5.32\end{array}$ & $<0.001$ & \\
\hline \multirow[t]{3}{*}{$\begin{array}{l}\text { Economic } \\
\text { status }\end{array}$} & $\begin{array}{l}\text { Lower than } \\
\text { intermediate }\end{array}$ & $34(24.1)$ & $\begin{array}{l}14.35 \pm \\
4.76\end{array}$ & $\begin{array}{l}8.62 \pm \\
6.47\end{array}$ & $<.001$ & \multirow[t]{3}{*}{0.426} \\
\hline & Intermediate & $93(66.0)$ & $\begin{array}{l}12.67 \pm \\
4.97\end{array}$ & $\begin{array}{l}7.44 \pm \\
5.41\end{array}$ & $<.001$ & \\
\hline & $\begin{array}{l}\text { Higher than } \\
\text { intermediate }\end{array}$ & $14(9.9)$ & $\begin{array}{l}12.40 \pm \\
4.35\end{array}$ & $\begin{array}{l}5.40 \pm \\
4.04\end{array}$ & $<.001$ & \\
\hline BMI & Normal & $48(34.0)$ & $\begin{array}{l}11.97 \pm \\
4.39\end{array}$ & $\begin{array}{l}6.68 \pm \\
5.00\end{array}$ & $<.001$ & 0.106 \\
\hline
\end{tabular}




\begin{tabular}{|c|c|c|c|c|c|c|}
\hline Variables & subgroups & $\begin{array}{l}\text { Frequency } N \\
(\%)\end{array}$ & $\begin{array}{l}\text { Before } \\
\text { mean } \pm \\
\text { SD }\end{array}$ & $\begin{array}{l}\text { After } \\
\text { mean } \pm \\
\text { SD }\end{array}$ & $\begin{array}{l}\mathrm{P}^{*}- \\
\text { value }\end{array}$ & $\begin{array}{l}\mathrm{P}^{* *}- \\
\text { value }\end{array}$ \\
\hline & Overweight & $66(46.0)$ & $\begin{array}{l}13.40 \pm \\
5.23\end{array}$ & $\begin{array}{l}8.42 \pm \\
5.88\end{array}$ & $\dot{0} 001$ & \\
\hline & Obese & $27(19.1)$ & $\begin{array}{l}14.07 \pm \\
4.65\end{array}$ & $\begin{array}{l}6.74 \pm \\
5.74\end{array}$ & $\dot{0} 001$ & \\
\hline $\begin{array}{l}\text { Duration of } \\
\text { LBP }\end{array}$ & $6-12$ & $38(27.0)$ & $\begin{array}{l}12.74 \pm \\
4.90\end{array}$ & $\begin{array}{l}6.50 \pm \\
5.46\end{array}$ & $\dot{0} 001$ & 0.335 \\
\hline \multirow[t]{3}{*}{ (Month) } & $13-48$ & $37(26.2)$ & $\begin{array}{l}13.12 \pm \\
4.36\end{array}$ & $\begin{array}{l}6.86 \pm \\
4.71\end{array}$ & $\begin{array}{l}< \\
0.001\end{array}$ & \\
\hline & $49-95$ & $31(22.0)$ & $\begin{array}{l}11.93 \pm \\
5.74\end{array}$ & $\begin{array}{l}7.48 \pm \\
6.05\end{array}$ & $<.001$ & \\
\hline & $96-180$ & $35(24.8)$ & $\begin{array}{l}14.31 \pm \\
4.48\end{array}$ & $\begin{array}{l}9.31 \pm \\
6.00\end{array}$ & $\begin{array}{l}< \\
0.001\end{array}$ & \\
\hline \multirow[t]{3}{*}{ MRI } & Mild & $108(76.6)$ & $\begin{array}{l}12.73 \pm \\
4.80\end{array}$ & $\begin{array}{l}7.20 \pm \\
5.36\end{array}$ & $<0.001$ & 0.943 \\
\hline & Moderate & $26(18.4)$ & $\begin{array}{l}14.23 \pm \\
5.39\end{array}$ & $\begin{array}{l}8.81 \pm \\
6.64\end{array}$ & $<.001$ & \\
\hline & Severe & $7(5.0)$ & $\begin{array}{l}13.57 \pm \\
3.82\end{array}$ & $\begin{array}{l}7.43 \pm \\
5.22\end{array}$ & $<.001$ & \\
\hline \multicolumn{7}{|c|}{$\begin{array}{l}\text { P-value*: With paired T-test. P-value **: Repeated measure ANOVA show difference of effect among } \\
\text { subgroups. }\end{array}$} \\
\hline \multicolumn{7}{|c|}{$\begin{array}{l}\text { SD: standard deviation; RMDQ: Roland-Morris Disability Questionnaire; N: number. BMI: body mass } \\
\text { index. MRI: magnetic resonance imaging. LBP: low back pain. }\end{array}$} \\
\hline
\end{tabular}

\section{Results of intervention effect on pain intensity based on NRS questionnaire}

The mean \pm SD of pain intensity before intervention was $5.42 \pm 6.09$ that changed to $2.98 \pm 1.64$ after intervention $(P<0.001)$ (Fig. 2). Analysis showed that mean \pm SD scores of NRS among all demographic and clinical characteristic variables were significant before and after intervention. Notably, there was no significant difference in variables for subgroups (Table 2). 
Table 2

Differences of Pain-intensity (NRS) mean \pm SD scores based on demographic variables

\begin{tabular}{|c|c|c|c|c|c|}
\hline Variables & Subgroups & $\begin{array}{l}\text { Before (mean } \pm \\
\text { SD) }\end{array}$ & $\begin{array}{l}\text { After (mean } \pm \\
\text { SD) }\end{array}$ & $\begin{array}{l}\mathrm{P} \text { - } \\
\text { value* }\end{array}$ & $\begin{array}{l}\mathrm{P} \text { - } \\
\text { value**}\end{array}$ \\
\hline \multirow[t]{2}{*}{ Age } & $\leq 40$ & $5.39 \pm 0.70$ & $2.85 \pm 1.78$ & $\begin{array}{l}< \\
0.001\end{array}$ & \multirow[t]{2}{*}{0.336} \\
\hline & $>40$ & $5.45 \pm 0.69$ & $3.18 \pm 1.39$ & $<.001$ & \\
\hline \multirow[t]{2}{*}{ Gender } & Male & $5.12 \pm 0.68$ & $3.02 \pm 1.67$ & $\begin{array}{l}< \\
0.001\end{array}$ & \multirow[t]{2}{*}{0.122} \\
\hline & Female & $5.53 \pm 0.67$ & $2.96 \pm 1.64$ & $<.001$ & \\
\hline \multirow[t]{2}{*}{ Marital status } & Single & $5.09 \pm 0.77$ & $2.62 \pm 1.46$ & $\begin{array}{l}< \\
0.001\end{array}$ & \multirow[t]{2}{*}{0.913} \\
\hline & Married & $5.47 \pm 0.68$ & $3.04 \pm 1.67$ & $\begin{array}{l}< \\
0.001\end{array}$ & \\
\hline \multirow[t]{2}{*}{ Education } & Diploma or less & $5.66 \pm 0.69$ & $3.13 \pm 1.70$ & $<.001$ & \multirow[t]{2}{*}{0.571} \\
\hline & Academic & $5.20 \pm 0.64$ & $2.84 \pm 1.59$ & $\begin{array}{l}< \\
0.001\end{array}$ & \\
\hline \multirow[t]{3}{*}{ Job } & Employed & $5.35 \pm 0.66$ & $3.05 \pm 1.58$ & $<.001$ & \multirow[t]{3}{*}{0.119} \\
\hline & Unemployed & $5.19 \pm 0.75$ & $2.15 \pm 1.59$ & $\begin{array}{l}< \\
0.001\end{array}$ & \\
\hline & Housewife & $5.64 \pm 0.67$ & $3.32 \pm 1.64$ & $\begin{array}{l}< \\
0.001\end{array}$ & \\
\hline \multirow[t]{2}{*}{ Residence } & Small city & $5.44 \pm 0.71$ & $3.04 \pm 1.47$ & $\hat{0}_{0.001}$ & \multirow[t]{2}{*}{0.830} \\
\hline & Large city & $5.40 \pm 0.71$ & $2.94 \pm 1.76$ & $\begin{array}{l}< \\
0.001\end{array}$ & \\
\hline \multirow[t]{3}{*}{ Economic status } & $\begin{array}{l}\text { Lower than } \\
\text { intermediate }\end{array}$ & $5.65 \pm 0.59$ & $3.00 \pm 1.77$ & $\hat{0}_{0.001}$ & \multirow[t]{3}{*}{0.148} \\
\hline & Intermediate & $5.35 \pm 0.73$ & $3.09 \pm 1.62$ & $\begin{array}{l}< \\
0.001\end{array}$ & \\
\hline & $\begin{array}{l}\text { Higher than } \\
\text { intermediate }\end{array}$ & $5.33 \pm 0.61$ & $2.27 \pm 1.39$ & $\begin{array}{l}<.001 \\
0\end{array}$ & \\
\hline BMI & Normal & $5.31 \pm 0.66$ & $3.10 \pm 1.57$ & $\dot{0}_{0.001}$ & 0.055 \\
\hline
\end{tabular}




\begin{tabular}{|c|c|c|c|c|c|}
\hline Variables & Subgroups & $\begin{array}{l}\text { Before (mean } \pm \\
\text { SD) }\end{array}$ & $\begin{array}{l}\text { After (mean } \pm \\
\text { SD) }\end{array}$ & $\begin{array}{l}\text { P- } \\
\text { value* }\end{array}$ & $\begin{array}{l}\mathrm{P}- \\
\text { value**}\end{array}$ \\
\hline & Overweight & $5.44 \pm 0.76$ & $3.11 \pm 1.72$ & $<.001$ & \\
\hline & Obese & $5.56 \pm 0.64$ & $2.45 \pm 1.53$ & $<0.001$ & \\
\hline \multirow[t]{4}{*}{$\begin{array}{l}\text { Duration of LBP } \\
\text { (Month) }\end{array}$} & $6-12$ & $5.26 \pm 0.76$ & $2.47 \pm 1.60$ & $\dot{0} 0.001$ & \multirow[t]{4}{*}{0.423} \\
\hline & $13-48$ & $5.43 \pm 0.65$ & $3.00 \pm 1.45$ & $<0.001$ & \\
\hline & $49-95$ & $5.45 \pm 0.72$ & $3.29 \pm 1.64$ & $<.001$ & \\
\hline & $96-180$ & $5.54 \pm 0.66$ & $3.23 \pm 1.82$ & $\dot{0} 001$ & \\
\hline \multirow[t]{3}{*}{ MRI } & Mild & $5.38 \pm 0.69$ & $2.96 \pm 1.61$ & $<.001$ & \multirow[t]{3}{*}{0.951} \\
\hline & Moderate & $5.42 \pm 0.64$ & $2.92 \pm 1.72$ & $<.001$ & \\
\hline & Severe & $6.00 \pm 0.82$ & $3.43 \pm 2.07$ & $<.001$ & \\
\hline
\end{tabular}

\section{Results of intervention effect on LBP improvement based on GRC questionnaire}

The mean \pm SD of the self-assessment for improvement of low back pain after intervention was $56.13 \pm$ $33.03 \%$. In addition, the relationship between GRC and demographic variables showed no significant difference (Table 3). 
Table 3

Mean \pm SD Percentage of GRC scores after intervention based on demographic variables

\begin{tabular}{|c|c|c|c|}
\hline Variables & & GRC Mean \pm SD & P-value \\
\hline \multirow[t]{2}{*}{ Age } & $\leq 40$ & $56.98 \pm 34.96$ & \multirow[t]{2}{*}{0.707} \\
\hline & $>40$ & $54.82 \pm 30.03$ & \\
\hline \multirow[t]{2}{*}{ Gender } & Male & $51.13 \pm 35.87$ & \multirow[t]{2}{*}{0.259} \\
\hline & Female & $58.12 \pm 31.81$ & \\
\hline \multirow[t]{2}{*}{ Marital status } & Single & $61.25 \pm 33.44$ & \multirow[t]{2}{*}{0.576} \\
\hline & Married & $56.13 \pm 33.41$ & \\
\hline \multirow[t]{2}{*}{ Education } & Diploma or less & $54.48 \pm 32.49$ & \multirow[t]{2}{*}{0.573} \\
\hline & Academic & $57.64 \pm 33.67$ & \\
\hline \multirow[t]{3}{*}{ Job } & Employed & $53.75 \pm 34.10$ & \multirow[t]{3}{*}{0.085} \\
\hline & Unemployed & $69.04 \pm 29.29$ & \\
\hline & Housewife & $52.45 \pm 32.32$ & \\
\hline \multirow[t]{2}{*}{ Residence } & Small city & $55.35 \pm 31.34$ & \multirow[t]{2}{*}{0.817} \\
\hline & Large city & $56.67 \pm 34.31$ & \\
\hline \multirow[t]{3}{*}{ Economic status } & Lower than intermediate & $55.29 \pm 34.38$ & \multirow[t]{3}{*}{0.674} \\
\hline & Intermediate & $55.27 \pm 33.18$ & \\
\hline & Higher than intermediate & $63.33 \pm 30.16$ & \\
\hline \multirow[t]{3}{*}{ BMI } & Normal & $55.63 \pm 31.70$ & \multirow[t]{3}{*}{0.205} \\
\hline & Overweight & $52.50 \pm 34.41$ & \\
\hline & Obese & $65.95 \pm 31.07$ & \\
\hline \multirow[t]{3}{*}{ MRI } & Mild & $56.76 \pm 31.80$ & \multirow[t]{3}{*}{0.916} \\
\hline & Moderate & $54.42 \pm 36.00$ & \\
\hline & Severe & $52.86 \pm 44.61$ & \\
\hline \multicolumn{4}{|c|}{$\begin{array}{l}\text { T- Test used. SD: standard deviation. GRC: Global Rating of Changes. LBP: Low Back Pain. BMI: Boc } \\
\text { Mass Index. MRI: Magnetic Resonance Imaging }\end{array}$} \\
\hline
\end{tabular}

Based on the RMDQ cut-off point, 88 participants $(62 \% ; 95 \% \mathrm{Cl}: 50-70)$ have been affected by chiropractic had a clinically meaningful effect. Multivariate logistic regression with RMDQ as dependent variable and economic status, NRS and GRC as independent variable, patients in higher economic status 
level had an odds of $170 \%$ (adjusted OR: $2.7 ; 95 \% \mathrm{Cl}: 1.09-6.51$ ) higher than who are in lower economic status level (Table 4).

Table 4

Logistic regression analysis between economic status and NRS and GRC

\begin{tabular}{|lll|}
\hline & $\begin{array}{l}\text { OR crud } \\
\text { (95\% confidence interval) }\end{array}$ & $\begin{array}{l}\text { OR adjusted } \\
\text { (95\%confidence interval) }\end{array}$ \\
\hline Higher economic status & $1.9(1.02-3.55)$ & $2.67(1.09-6.51)$ \\
\hline NRS & $0.04(.01-.11)$ & $.22(.62-.79)$ \\
\hline GRC & $1.05(1.04-1.07)$ & $1.05(1.02-1.07)$ \\
\hline NRS: Numerical Rating Scale. GRC: Global Rating of Changes. OR: odd's ratio. \\
\hline
\end{tabular}

\section{Discussion}

In this study, three criteria of standard assessment of LBP including RMDQ, NRS and GRC reveal that disability level, pain intensity and, LBP improvement in pain or disease, before and after chiropractic were evaluated. The results of this study showed that chiropractic is effective in pain disability, pain intensity and global LBP improvement. However, not all associated factors were relevant as a result of chiropractic intervention, except that Job status was an important associated factors with the treatment impact, in this regard, unemployment had a strong response to chiropractic intervention.

The results of this study confirmed that chiropractic resulted in a significant reduction in RMDQ score of chronic LBP before and after intervention (mean difference $=5.54$ ), which indicates that chiropractic may be effective in reducing disability due to LBP. In a study conducted by Goertz et al. on 750 patients, the mean difference of disability for chronic LBP before and after intervention was 4.6, using the RMDQ, reaching similar result in the present study (30). In addition, all patients in current study had chronic LBP, but in Mortensen et al. study the chiropractic effects on acute, sub-acute and chronic LBP were compared and the results revealed that the most effective chiropractic care was in acute LBP, then in sub-acute and the least effect was related to chronic LBP (31). In this study, although mean difference of therapeutic effect on all these demographic variables was significant, further analysis compared between subgroups variables showed that only job demographic variable had a significant effect in subgroups. In other word, the unemployed patients had the highest level of disability compared to the employed and housewives. Hence, the importance of occupation, ergonomic, and required resting in therapeutic effectiveness of chiropractic in LBP was suggested.

In case of NRS, it is perceived that the total mean difference of pain intensity before and after the intervention was 2.44, which is statistically significant and in line with other studies (30). In the Goertz et al. study, the effect of chiropractic on the treatment of chronic LBP was assessed, using the NRS pain instrument. The results presented a significant therapeutic effect (30). In Brigitte Worth et al., 67 LBP 
patients who were referred from the neurosurgery clinic to the chiropractic centers, the mean difference in pain intensity was assessed through a 12-month follow-up NRS questionnaire, which showed that pain intensity was reduced after chiropractic treatment (mean difference 3.7) (32). These results also showed that the rate of LBP intensity had decreased within three months to one year after treatment.

In case of GRC, the patients had a mean improvement rate of $56.13 \% \pm 33.03$. In the Brigitte et al. study, the mean rate of LBP patients' improvement after chiropractic intervention was reduced after one, three and 12 months (32). As these studies showed that the chiropractic effect in treating LBP had not a transient effect and its therapeutic effect remained for up to one year. The results of other studies also showed the effectiveness of chiropractic as a conservative treatment alternative in treating $\operatorname{LBP}(33,34)$.

Based on the RMDQ cut-off point, 88 participants $(62 \% ; 95 \% \mathrm{Cl}: 50-70)$ have been affected by chiropractic with a clinically meaningful effect (Table 4). There are limited studies that evaluated clinically meaningful effect after chiropractic modality. According to the study of Weeks et al., on elderly patients with chronic LBP who used chiropractic therapy as the first line of treatment during LBP attack, the overall cost of treatment and the length of each attack was reduced (35). The result of current study consistent with Christine et al. that showed that the addition of chiropractic care to the usual medical care can improve the disability and pain intensity reduction in LBP, without report meaningful effect. This study findings support existing guidelines that recommend non-pharmacological treatments as a first-line of treatment for $\operatorname{LBP}(30,36)$ Therefore, it appears that chiropractic intervention need more attention in the further LBP treatment guideline.

However, no previous study evaluated the MRI of LBP patients; hence, MRI evaluation is the strength point of this study. The results of this study revealed that chiropractic care can have an acceptable role in the treatment of patients with nonspecific chronic LBP, even in patients with severe pain and severe MRI findings. Hence, the chiropractic may be an effective therapeutic modality in treating patients with mild, moderate, or even severe MRI findings. Therefore, it may be effective in preventing many lumbosacral intervertebral disc surgeries.

This study had some limitations: In this study, only three characteristics of primary outcomes were evaluated, and was limited to evaluate secondary outcomes such as quality of life and return to work. Moreover, this study only evaluated the therapeutic effect in patients with chronic LBP and the duration of follow-up was only 8 weeks, which was due to financial limitations. Moreover, due to our inaccessibility to other patients that had referred to orthopedic clinics and enrolling some to receive chiropractic care; hence, we could not have a control group to make a comparison.

\section{Conclusion}

With the increasing acceptance of chiropractic as a complementary therapeutic approach in the treatment of LBP, there is a need to scientifically evaluate the efficacy of this therapy. Since this study was able to find that chiropractic therapy may be effective in reducing disability as result of LBP and reducing the intensity of pain in chronic LBP patients; On the other hand, since the therapeutic effect of 
chiropractic evaluated based on different demographic variables and subgroups, hence, it gives the impression that majority of chronic LBP patients might benefit from chiropractic intervention.

Chiropractic intervention appears to need more attention in the further LBP treatment guidelines.

\section{Abbreviations}

LBP: Low Back pain; RMDQ:Roland Morris Disability Questionnaire; NRS:Numerical Rating Scale; GRC:Global Rating of Change; BMI:body mass index; RCT:Randomized controlled trial

\section{Declarations}

\section{Availability of data and materials}

Data available upon request include responses from dimension questions and respondent's role. Identification of respondent's institution will not be available per respective data agreements. Data requests can be made to corresponding author (ORCID iD0000-0002-9927-5922). Reuse of data is not permitted without authorization from the authorship team.

Ethics approval and consent to participate

This study was approved by the local Ethics Committee of Shiraz University of Medical Sciences (IR.SUMS.REC.1399.032).

Consent for publication

Not applicable.

\section{Competing interests}

The authors declare that they have no competing interests.

\section{Funding}

None.

\section{Authors' contributions}

A.R. Salehi; M.H. Sharifi and B. Aleali the conception and design of the study. M Sousani analyzed and interpreted the patient data the Low Back pain; M.H. Sharifi, A.R. Salehi and M. Sousani article or revising it critically for important intellectual content; All authors have agreed to the final version. 


\section{Acknowledgment}

The authors wish to thank Mr. H. Argasi at the Research Consultation Center (RCC) of Shiraz University of Medical Sciences for his invaluable assistance in editing this manuscript.

\section{References}

1. Gaskin DJ, Richard P. The economic costs of pain in the United States. The J Pain 2012;13(8):71524.

2. Murray C. The global burden of disease: Generating evidence, guiding policy. Seattle, Washington: Institute for Health Metrics and Evaluation. 2013.

3. Mohamad-Zeidi E, Khalaj M, MM N-J. Quality of life in people with low back pain. Iranian Journal of Aging. 2006;1(2):119-24.

4. Balagué F, Mannion AF, Pellisé F, Cedraschi C. Non-specific low back pain. The lancet. 2012;379(9814):482-91.

5. Machado GC, Maher CG, Ferreira PH, Day RO, Pinheiro MB, Ferreira ML. Non-steroidal antiinflammatory drugs for spinal pain: a systematic review and meta-analysis. Ann Rheum Dis. 2017;76(7):1269-78.

6. Brummett CM, Waljee JF, Goesling J, Moser S, Lin P, Englesbe MJ, et al. New persistent opioid use after minor and major surgical procedures in US adults. JAMA surgery. 2017;152(6):e170504-e.

7. Hurwitz EL. The relative impact of chiropractic vs. medical management of low back pain on health status in a multispecialty group practice. J Manipulative Physiol Ther. 1994;17(2):74-82.

8. Singh S, Ernst E. Trick or treatment: The undeniable facts about alternative medicine: WW Norton \& Company; 2008.

9. Davis PT, Hulbert JR, Kassak KM, Meyer JJ. Comparative efficacy of conservative medical and chiropractic treatments for carpal tunnel syndrome: a randomized clinical trail. J Manipulative Physiol Ther. 1998;21(5):317-26.

10. Fallon J. The role of the chiropractic adjustment in the care and treatment of 332 children with otitis media. Journal of Clinical Chiropractic Pediatrics. 1997;2(2):167-83.

11. Christensen M, Kerkhoff D, Kollasch MG. CO: National Board of Chiropractic Examiners; Job Analysis of Chiropractic; 2005.

12. Wolsko PM, Eisenberg DM, Davis RB, Kessler R, Phillips RS. Patterns and perceptions of care for treatment of back and neck pain: results of a national survey. Spine. 2003;28(3):292-7.

13. Barnes PM, Bloom B, Nahin RL. Complementary and alternative medicine use among adults and children; United States, 2007. 2008.

14. Carey TS, Garrett J, Jackman A, McLaughlin C, Fryer J, Smucker DR, et al. The outcomes and costs of care for acute low back pain among patients seen by primary care practitioners, chiropractors, and orthopedic surgeons. N Engl J Med . 1995;333(14):913-7. 
15. Cherkin DC, MacCornack FA. Patient evaluations of low back pain care from family physicians and chiropractors. Western Journal of Medicine. 1989;150(3):351.

16. Weigel PA, Hockenberry JM, Wolinsky FD. Chiropractic use in the Medicare population: prevalence, patterns, and associations with 1-year changes in health and satisfaction with care. J Manipulative Physiol Ther. 2014;37(8):542-51.

17. Ernst $\mathrm{E}$, Canter $\mathrm{PH}$. Chiropractic spinal manipulation treatment for back pain? A systematic review of randomised clinical trials. Physical therapy reviews. 2003;8(2):85-91.

18. Salehi A, Hashemi N, Imanieh MH, Saber M. Chiropractic: is it efficient in treatment of diseases? Review of systematic reviews. Int J Community Based Nurs Midwifery. 2015;3(4):244.

19. Eklund A, Jensen I, Lohela-Karlsson M, Hagberg J, Leboeuf-Yde C, Kongsted A, et al. The Nordic Maintenance Care program: Effectiveness of chiropractic maintenance care versus symptom-guided treatment for recurrent and persistent low back pain-A pragmatic randomized controlled trial. PloS one. 2018;13(9):e0203029.

20. Maharlouei N, Akbari M, Akbari M, Lankarani KB. Socioeconomic status and satisfaction with public healthcare system in Iran. Int J Community Based Nurs Midwifery. 2017;5(1):22.

21. Pfirrmann CW, Metzdorf A, Zanetti M, Hodler J, Boos N. Magnetic resonance classification of lumbar intervertebral disc degeneration. Spine. 2001;26(17):1873-8.

22. Smeets R, Köke A, Lin CW, Ferreira M, Demoulin C. Measures of function in low back pain/disorders: Low Back Pain Rating Scale (LBPRS), Oswestry Disability Index (ODI), Progressive Isoinertial Lifting Evaluation (PILE), Quebec Back Pain Disability Scale (QBPDS), and Roland-Morris Disability Questionnaire (RDQ). Arthritis Care Res. 2011;63(S11):S158-S73.

23. Mousavi SJ, Parnianpour M, Mehdian H, Montazeri A, Mobini B. The Oswestry disability index, the Roland-Morris disability questionnaire, and the Quebec back pain disability scale: translation and validation studies of the Iranian versions. Spine. 2006;31(14):E454-E9.

24. Stratford PW. Using the Roland-Morris Questionnaire to make decisions about individual patients. Physiotherapy Can. 1996;48:107-10.

25. Roland M, Morris R. A study of the natural history of back pain. Part 1: development of a reliable and sensitive measure of disability in low back pain. Spine (Phila Pa 1976). 1983; 8 (2): 141-4.

26. Jordan K, Dunn KM, Lewis M, Croft P. A minimal clinically important difference was derived for the Roland-Morris Disability Questionnaire for low back pain. J Clin Epidemiol. 2006;59(1):45-52.

27. Jensen MP, Karoly P. Self-report scales and procedures for assessing pain in adults. Handbook of pain assessment. New York, NY, US: The Guilford Press; 1992. p. 135-51.

28. Childs JD, Piva SR, Fritz JM. Responsiveness of the numeric pain rating scale in patients with low back pain. Spine. 2005;30(11):1331-4.

29. Foroutani H, Nakhostin Ansari N, Ansari N, Jalaei S. Investigating the responsiveness of the Persian version of functional rating index in patients with chronic non-specific neck pain: brief report. Tehran University Medical Journal TUMS Publications. 2018;76(7):498-502. 
30. Goertz CM, Long CR, Vining RD, Pohlman KA, Walter J, Coulter I. Effect of usual medical care plus chiropractic care vs usual medical care alone on pain and disability among US service members with low back pain: A comparative effectiveness clinical trial. JAMA network open. 2018;1(1):e180105-e.

31. Hare-Mortensen L, Lauridsen $\mathrm{H}$, Grunnet-Nilsson N. The relative responsiveness of 3 different types of clinical outcome measures on chiropractic patients with low back pain. J Manipulative Physiol Ther. 2006;29(2):95-9.

32. Wirth B, Riner F, Peterson C, Humphreys BK, Farshad M, Becker S, et al. An observational study on trajectories and outcomes of chronic low back pain patients referred from a spine surgery division for chiropractic treatment. Chiropr Man Therap. 2019;27(1):6.

33. Rubinstein SM, van Middelkoop M, Assendelft WJ, de Boer MR, van Tulder MW. Spinal manipulative therapy for chronic low-back pain. Cochrane Database Syst Rev. 2011(2).

34. Walker BF, French SD, Grant W, Green S. A Cochrane review of combined chiropractic interventions for low-back pain. Spine. 2011;36(3):230-42.

35. Weeks WB, Leininger B, Whedon JM, Lurie JD, Tosteson TD, Swenson R, et al. The association between use of chiropractic care and costs of care among older Medicare patients with chronic low back pain and multiple comorbidities. J Manipulative Physiol Ther. 2016;39(2):63-75. e2.

36. Qaseem A, Wilt TJ, McLean RM, Forciea MA. Noninvasive treatments for acute, subacute, and chronic low back pain: a clinical practice guideline from the American College of Physicians. Ann Intern Med. 2017;166(7):514-30.

\section{Figures}




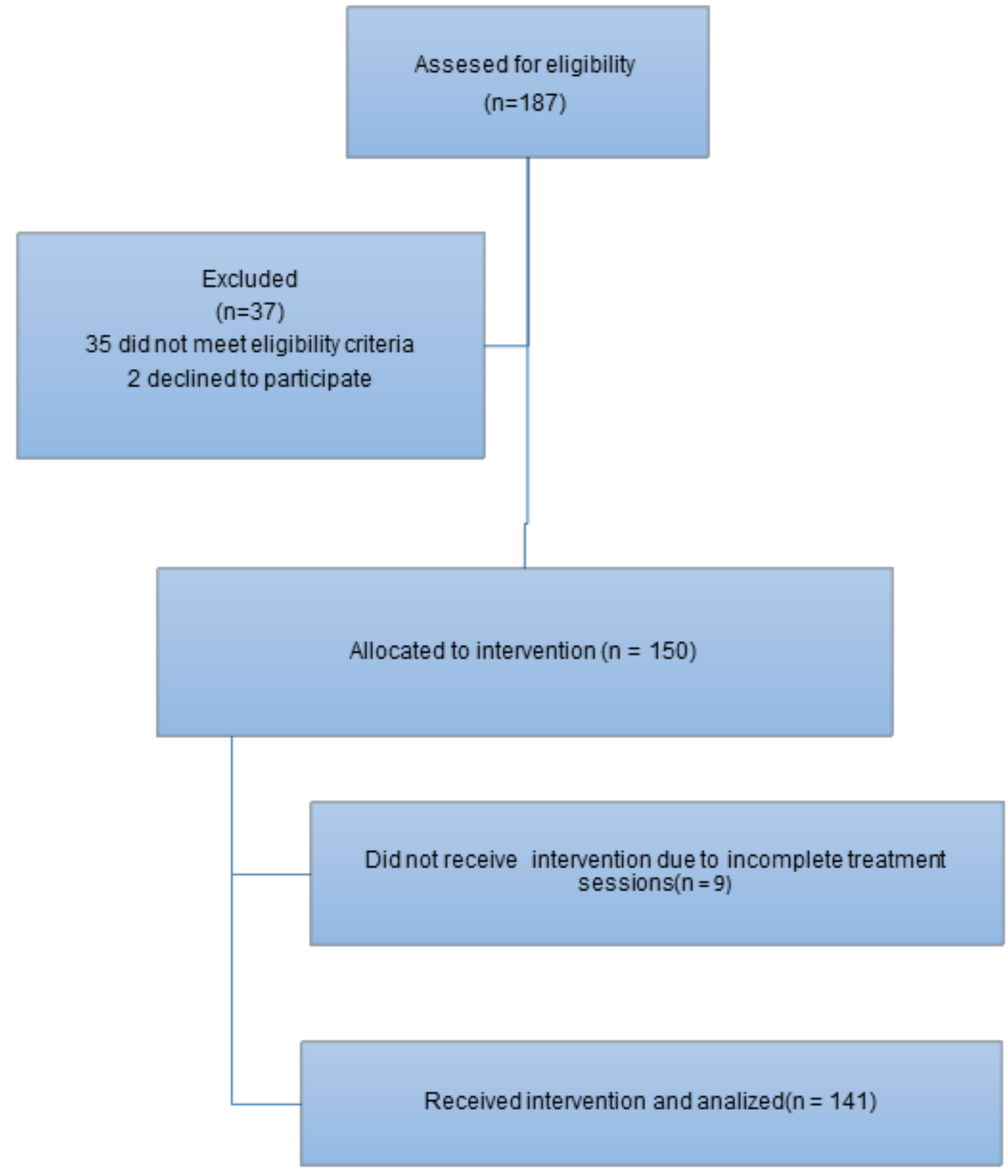

\section{Figure 1}

Study flow chart 


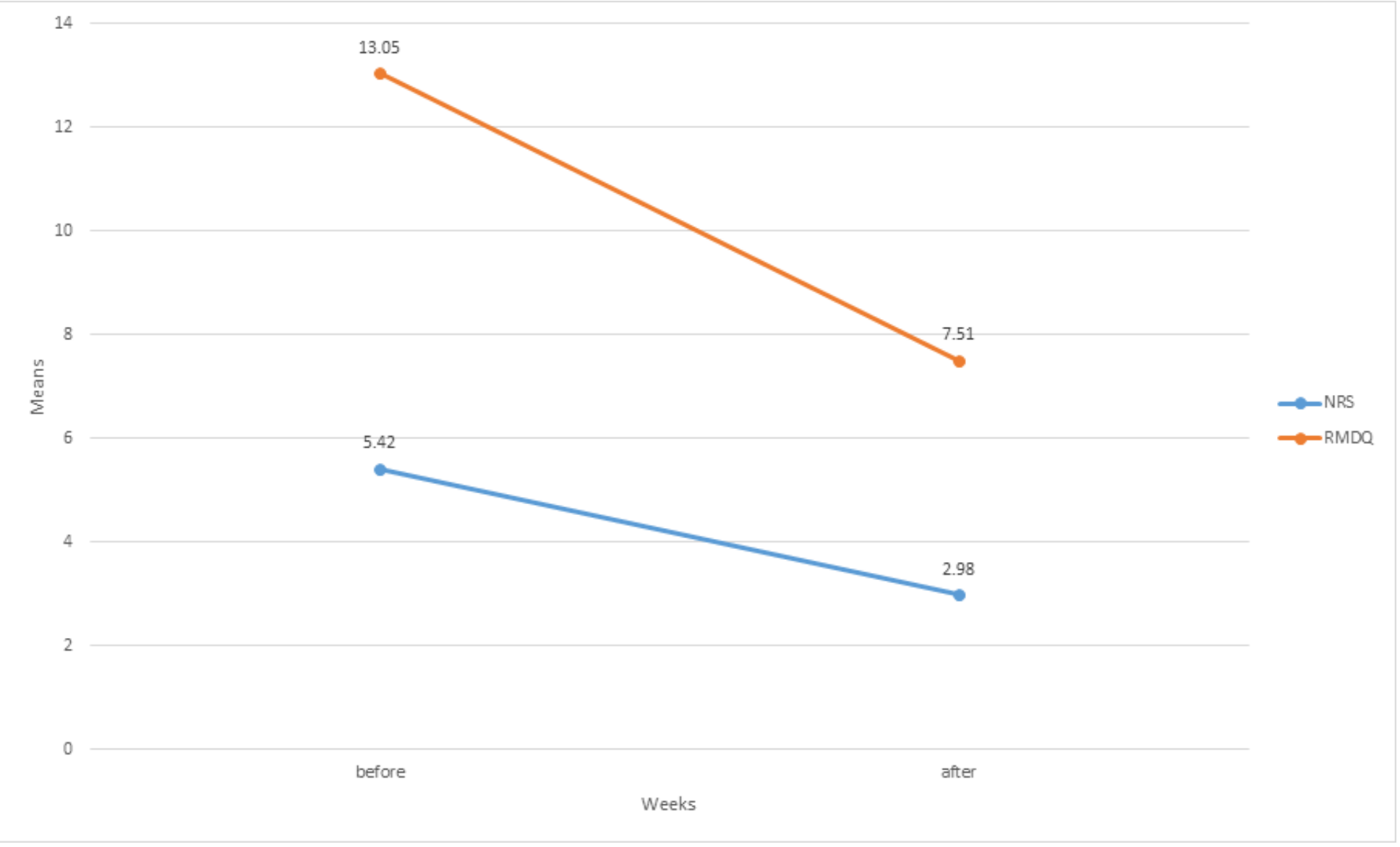

Figure 2

Mean differences of RMDQ (pain disability) and NRS (pain intensity) before and after intervention 